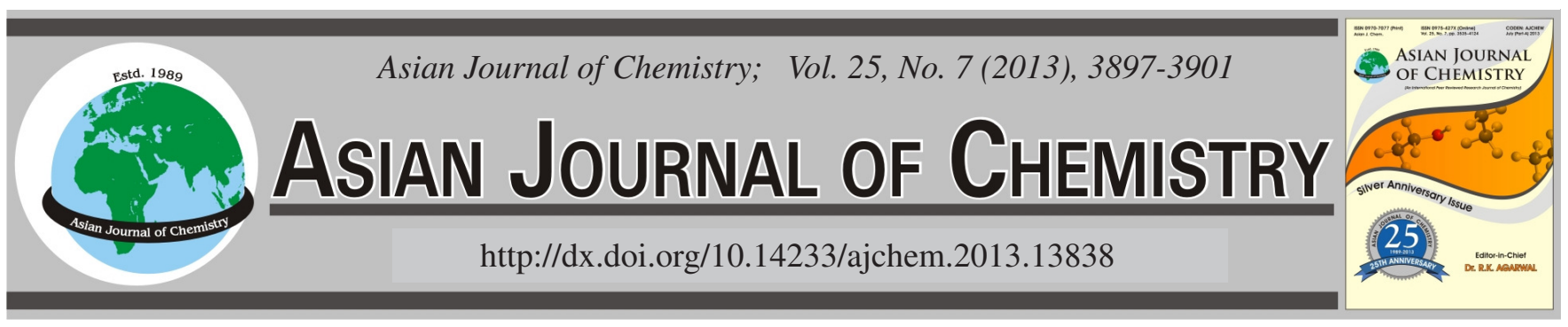

\title{
Thermodynamic and Experimental Analysis on Vacuum Silicothermic Reduction of MgO in Molten Slags
}

\author{
Qifeng TANG ${ }^{1,2}$, JiACHENG GAO $^{1,2, *}$ and XIAOHUA ChEN ${ }^{1,2}$
}

${ }^{1}$ College of Materials Science and Engineering, Chongqing University, Chongqing 400044, P.R. China

${ }^{2}$ National Engineering Research Center for Magnesium Alloys, Chongqing University, Chongqing 400044, P.R. China

*Corresponding author: Tel: +86 13509474466; E-mail: gaojch@cqu.edu.cn

Smelting reduction, a new magnesium production process, has been investigated. At high temperature, appropriate mixture of $\mathrm{Al}_{2} \mathrm{O}_{3}$ and $\mathrm{SiO}_{2}$ with calcined dolomite can make charge to form molten slag and reduction reaction take place between liquid $\mathrm{MgO}$ and liquid ferrosilicon. Smelting reduction on molten slag of the compositon $55 \%$ calcined dolomite ( $32 \% \mathrm{CaO}$ and $23 \% \mathrm{MgO}^{2}, 35 \% \mathrm{Al}_{2} \mathrm{O}_{3}, 10 \%$ $\mathrm{SiO}_{2}$ reacted with ferrosilicon was studied. By thermodynamic analysing, the semlting reduction could react at $1873 \mathrm{~K}$ under atmosphere. The experiments of semlting reduction were carried out under vacuum for avoiding re-oxidation of $\mathrm{Mg}$ vapour and the results showed that reduction extent of $\mathrm{MgO}$ was achieved up to $97 \%$ with $1 \mathrm{X}$ silicon stoichiometry at $1873 \mathrm{~K}$ for $2 \mathrm{~h}$.

Key Words: Slag, Calcined dolomite, Smelting reduction, Thermodynamic analysis, Silicothermic reduction.

ᄂ - - - - - - - - - - - - - - - - - - - - - - - - - -

\section{INTRODUCTION}

Magnesium production by Pidgeon process uses ferrosilicon to reduce $\mathrm{MgO}$ from calcined dolomite and China becomes the largest primary magnesium producer in the world because of having abundant dolomite resources ${ }^{1,2}$. Reaction in Pidgeon process takes place in solid state, so the duration of completely-reduced $\mathrm{MgO}$ is quite long because of too slow reaction rate. Due to such disadvantages of Pidgeon process, it is necessary to develop new magnesium production technologys with low pollution and energy cost.

Smelting reduction technology is a new metallurgical process in which oxides in liquid slag state are reduced to liquid or gaseous metals. Smelting reduction takes place in liquid state, which can accelerate reaction rate and improve productivity. In recent years, smelting reduction has gained increasing importance to produce metal, such as Fe, Mn, Zn, $\mathrm{Cr}^{3-6}$. Most literatures on the $\mathrm{Mg}$ production from dolomite or Magnesite focused on solid phase reduction ${ }^{7-11}$. The studies on smelting reduction of $\mathrm{MgO}$ have seldomly published except for the patents. The reduction of $\mathrm{MgO}$ in molten slag with the composition of $5.6 \% \mathrm{MgO}, 48.1 \% \mathrm{Al}_{2} \mathrm{O}_{3}$ and $46.3 \% \mathrm{CaO}$ reacting with ferroaluminium $(80 \% \mathrm{Al}$ and $35 \% \mathrm{Al})$ had been reported by Capocchi and Rajakumar ${ }^{12}$. The content of $\mathrm{MgO}$ in slag was low and the composition of slag was not applied to smelting reduction of $\mathrm{MgO}$ from dolomite.
The aim of this work was to study silicothermic smelting reduction of $\mathrm{MgO}$ from calcined dolomite in molten slags though thermodynamic and experimental analysis. This research was expected to widen the understanding of the extraction for $\mathrm{Mg}$ from dolomite by smelting reduction.

Thermodynamic analysis: Calcined dolomite mainly composed of $\mathrm{CaO}$ and $\mathrm{MgO}\left(\mathrm{n}_{\mathrm{CaO}} / \mathrm{n}_{\mathrm{MgO}}=1\right)$, together with a small amount of other oxide impurities(less $2 \%$ ). $\mathrm{CaO}$ and $\mathrm{MgO}$ are alkaline earth oxides and have very high melting temperatures. In order to get molten slag between 1773 and $1873 \mathrm{~K}$, it is required to mix appropriate $\mathrm{Al}_{2} \mathrm{O}_{3}$ and/or $\mathrm{SiO}_{2}$ with calcined dolomite.

At high temperature, $\mathrm{MgO}$ is liquid state in slag and reacts with liquid ferrosilicon as reducing agent. The overall reaction that occurs in this process can be expressed by the equation:

$$
2 \mathrm{MgO}_{(1)}+\mathrm{Si}_{(\mathrm{l})}=2 \mathrm{Mg}_{(\mathrm{g})}+\mathrm{SiO}_{2(1)}
$$

Because reactant $\mathrm{MgO}$ and resultant $\mathrm{SiO}_{2}$ are liquid states in smelting reduction, before analyze thermodynamics of eqn. 1 , it is necessary to calculate the standard enthalpy and entropy of these two liquid oxides under 1 atm and 298 K. As status function, enthalpy and entropy just lie on the first and finally status. So the melting process of solid oxides at $1873 \mathrm{~K}$ was shown in Fig. 1. The results of thermodynamic calculation were as follows: $\Delta \mathrm{H}^{\mathrm{o}}{ }_{298(\mathrm{MGO})(\mathrm{l})}=-545.345 \mathrm{~kJ} / \mathrm{mol}$, 


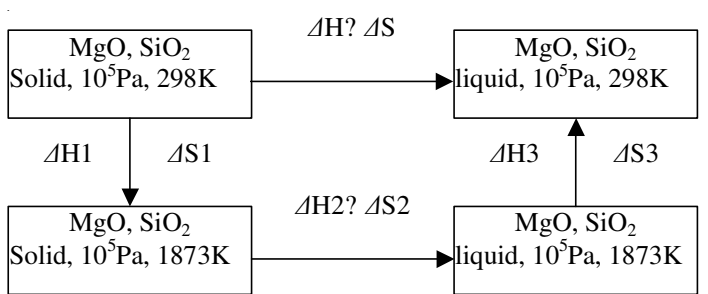

Fig. 1. Melting process of solid oxides

$\Delta \mathrm{S}^{\mathrm{o}}{ }_{298(\mathrm{MgO})(1)}=27.004 \mathrm{~J} /(\mathrm{mol} \mathrm{K}), \Delta \mathrm{H}^{\mathbf{o}}{ }_{298\left(\mathrm{SiO}_{2}\right)(1)}=-896.796$ $\mathrm{kJ} / \mathrm{mol}, \Delta \mathrm{S}_{298\left(\mathrm{SiO}_{2}\right)(1)}^{\mathrm{o}}=50.829 \mathrm{~J} /(\mathrm{mol} \mathrm{K})$.

Based on formula $\Delta \mathrm{G}^{\mathrm{o}}=\Delta \mathrm{H}^{\mathrm{o}}-\mathrm{T} \times \Delta \mathrm{S}^{\mathrm{o}}$, the standard Gibbs free energy of eqn. 1 is depicted as follow:

$$
\Delta \mathrm{G}^{\mathrm{o}}=388745-176.84 \mathrm{~T}
$$

By calculating eqn. 2, the starting temperature of silicothermic reduction of $\mathrm{MgO}$ in molten slag was above 2198 $\mathrm{K}$ under atmosphere. This temperature was higher than the maximum operating temperature of experimental furnace. Vacuum was used to decrease the starting temperature of silicothermic reduction and avoid re-oxygenation of $\mathrm{Mg}$ vapour. Moreover, activities of $\mathrm{MgO}$ and $\mathrm{SiO}_{2}$ in slag and $\mathrm{Si}$ in ferrosilicon also affected smelting reduction process. From the above analyses, the reaction could not be processed under standard status in real reduction. The possibility of smetling reduction of $\mathrm{MgO}$ must be decided by the real Gibbs free en$\operatorname{ergy}(\Delta \mathrm{G})$ and $\Delta \mathrm{G}$ is given by the eqn. 3 :

$$
\Delta \mathrm{G}=\Delta \mathrm{G}^{\mathrm{o}}+\mathrm{RT} \ln \mathrm{K}
$$

where $\mathrm{R}$ is gas constant and $\mathrm{K}$ is equilibrium constant.

The equilibrium constant $\mathrm{K}$ is defined as follow:

$$
\mathrm{K}=\left(\mathrm{P}_{\mathrm{Mg}^{2}} \mathrm{a}_{\mathrm{SiO}_{2}}\right) /\left(\mathrm{a}_{\mathrm{MgO}} \cdot \mathrm{aSi}\right)
$$

where $\mathrm{P}_{\mathrm{Mg}}=$ magnesium vapour pressure at the slag metal interface, $\mathrm{a}_{\mathrm{SiO}_{2}}=$ activity of $\mathrm{SiO}_{2}$ in salg, $\mathrm{a}_{\mathrm{MgO}}=$ activity of $\mathrm{MgO}$ in salg, $\mathrm{a}_{\mathrm{Si}}=$ activity of silicon in the ferrosilicon alloy.

Simultaneous eqns. 2-4, relationship of $\Delta \mathrm{G}$ to equilibrium temperature and pressure of system in different slag can be acquired.

In previous work, slag containing $55 \%$ calcined dolomite and $45 \%$ additive $\left(\mathrm{Al}_{2} \mathrm{O}_{3}\right.$ and $\left.\mathrm{SiO}_{2}\right)$ can be molten at $1873 \mathrm{~K}^{13}$. In this study, the chemical composition of experimental slag and activity of reactant and resultant were given in Table-1. By calculation, relationship of $\Delta \mathrm{G}$ to equilibrium temperature and pressure of system in this slag were given in Table-2.

TABLE-1

CHEMICAL COMPOSITION OF EXPERIMENTAL SLAG [wt. \%] AND ACTIVITY OF REACTANT AND RESULTANT

\begin{tabular}{cccccc}
\hline \multicolumn{2}{c}{$\begin{array}{c}\text { Chemical composition of } \\
\text { experimental slag }\end{array}$} & \multicolumn{4}{c}{$\begin{array}{c}\text { Activity of reactant and } \\
\text { resultant }\end{array}$} \\
\hline $\begin{array}{c}\text { Calcined dolomite } \\
(\mathrm{CaO} \cdot \mathrm{MgO})\end{array}$ & $\mathrm{Al}_{2} \mathrm{O}_{3}$ & $\mathrm{SiO}_{2}$ & $\begin{array}{c}\mathrm{a}_{\mathrm{Si}}(75 \% \\
\mathrm{SiFe})\end{array}$ & $\mathrm{a}_{\mathrm{MgO}}$ & $\mathrm{a}_{\mathrm{SiO}_{2}}$ \\
\hline 55 & 35 & 10 & 0.9 & 0.14 & $3.6 \times 10^{-4}$ \\
\hline
\end{tabular}

It was well known from Table-2 that reduction of $\mathrm{MgO}$ in slag can react at $1873 \mathrm{~K}$ under atmosphere and higher tempe-

\begin{tabular}{|c|c|c|c|c|}
\hline \multicolumn{5}{|c|}{$\begin{array}{c}\text { TABLE-2 } \\
\text { RELATIONSHIP OF } \Delta \text { G TO TEMPERATURE } \\
\text { AND PRESSURE OF SYSTEM IN SLAG }\end{array}$} \\
\hline \multirow{2}{*}{$\begin{array}{c}\mathrm{T} \\
(\mathrm{K})\end{array}$} & \multicolumn{4}{|c|}{$\Delta \mathrm{G}$} \\
\hline & $\mathrm{P}=10^{5}(\mathrm{~Pa})$ & $\mathrm{P}=10^{4}(\mathrm{~Pa})$ & $\mathrm{P}=10^{3}(\mathrm{~Pa})$ & $\mathrm{P}=10^{2}(\mathrm{~Pa})$ \\
\hline 1723 & 28138 & -37831 & -103800 & -169769 \\
\hline 1773 & 17674 & -50210 & -118093 & -185977 \\
\hline 1823 & 7209 & -62589 & -132387 & -202185 \\
\hline 1873 & -3255 & -74968 & -146680 & -218392 \\
\hline 1923 & -13720 & -87346 & -160973 & -234600 \\
\hline 1973 & -24184 & -99725 & -175266 & -250807 \\
\hline
\end{tabular}
rature and/or lower system pressure can make smelting reduction process easier. During the smelting reduction, activity of $\mathrm{SiO}_{2}$ will increase and activity of $\mathrm{MgO}$ and $\mathrm{Si}$ will decrease because of composition changes in slag and ferrosilicon. For avoiding re-oxidation of $\mathrm{Mg}$ vapour, vacuum will continue to be used in smelting reduction of $\mathrm{MgO}$.

\section{EXPERIMENTAL}

Raw materials: The experimental dolomite ores were supplied by the Chongqing Haibo magnesium smelting Co., Ltd. The chemical composition of the dolomite sample was given in Table-3. The dolomite ores were calcined at $1273 \mathrm{~K}$ for $1 \mathrm{~h}$ and pulverized to powder which passed through the 200-mesh sieve.

\begin{tabular}{cccc}
\multicolumn{5}{c}{ TABLE-3 } \\
\multicolumn{4}{|c}{ CHEMICAL COMPOSITION OF DOLOMITE [wt. \%] } \\
\hline $\mathrm{CaO}$ & $\mathrm{MgO}$ & $\mathrm{SiO}_{2}$ & Burning loss \\
\hline 29.46 & 20.97 & 1.60 & 46.40 \\
\hline
\end{tabular}

Pure grade $\mathrm{Al}_{2} \mathrm{O}_{3}$ and $\mathrm{SiO}_{2}$ were used as slagging agents and $\mathrm{CaF}_{2}$ of reagent grade was used as catalyst in this study. The chemical composition of experimental primary slag mixed by calcined dolomite and additive was given in Table- 4 .

\begin{tabular}{ccccc}
\multicolumn{5}{c}{ TABLE-4 } \\
& \multicolumn{3}{c}{ CHEMICAL COMPOSITION OF } \\
& EXPERIMENTAL PRIMARY SLAG [wt. \%] & \\
\hline $\mathrm{CaO}$ & $\mathrm{MgO}$ & $\mathrm{SiO}_{2}$ & $\mathrm{Al}_{2} \mathrm{O}_{3}$ & $\mathrm{CaF}_{2}$ \\
\hline 33.08 & 22.92 & 9.45 & 32.55 & 3.00 \\
\hline
\end{tabular}

The experimental ferrosilicon ores were used as reductant provided by the Chongqing Haibo magnesium smelting Co., Ltd. The chemical composition of the ferrosilicon sample contains in weight percentage: $76.4 \% \mathrm{Si}, 23.1 \% \mathrm{Fe}$ and others impurities. The ferrosilicon ores were ground with agate mortar and pestle. All of the powder passed through the 200-mesh sieve.

Equipment: The reduction process was carried out in the high-temperature vacuum furnace. The furnace was internally heated by using a regulated graphite resistance and had a maximum temperature of $1873 \mathrm{~K}$ and a limit vacuum $0.01 \mathrm{~Pa}$. Chemical compositions of the slags were measured using X-ray fluorescence (XRF-1800).

Mineralogical investigation was analyzed by XRD (D/max $1200 \mathrm{X}$-ray diffractometer). The experimental conditions were as follows: $45 \mathrm{kV}, 40 \mathrm{~mA}$, no filter, $2 \theta=10-80^{\circ}$, continuous scan with rate $3 \%$ min and step size of $0.03^{\circ}$.

Experimental procedure: Charges consisting of calcined dolomite, $\mathrm{Al}_{2} \mathrm{O}_{3}, \mathrm{SiO}_{2}, \mathrm{CaF}_{2}$ and ferrosilicon were compacted 
into $10 \mathrm{~mm}$-diameter and $30 \mathrm{~mm}$-height pellets. The charged graphite crucible with $150 \mathrm{~g}$ mixture was laid in the furnace at room temperature. In order to help reduction processing, the system pressure was controled under 4-40 Pa. The experimental temperature was controled at $1773-1873 \mathrm{~K}$ due to the limitation of the maximum operating temperature of the furnace. After reduction processing under different experimental condition, the slag in graphite crucible was cooled to room temperature. The chemical composition and mineralogical investigation of the residue obtained were analyzed by XRF and XRD.

\section{RESULTS AND DISCUSSION}

Reduction extent of $\mathrm{MgO}$ was measured for the smelting reaction which takes place between $\mathrm{MgO}$ in molten $\mathrm{CaO}-\mathrm{MgO}$ $\mathrm{Al}_{2} \mathrm{O}_{3}-\mathrm{SiO}_{2}-\mathrm{CaF}_{2}$ slag and ferrosilicon under high-temperature and vacuum condition. The effect of temperature, $\mathrm{CaF}_{2}$, reduction time and ferrosilicon stoichiometry were studied. The reduction extent of $\mathrm{MgO}$ in slag was defined by the eqn. 5:

$$
\eta=\left[\frac{1-\mathrm{W}_{(\mathrm{MgO}) \mathrm{t}}}{\mathrm{W}_{(\mathrm{MgO}) 0}} \times 100 \%\right]
$$

where $\mathrm{W}_{(\mathrm{MgO}) \mathrm{t}}$ is the weight of $\mathrm{MgO}$ in the slag at any time $\mathrm{t}$ and $\mathrm{W}_{(\mathrm{MgO}) 0}$ is the weight of $\mathrm{MgO}$ in the slag at $\mathrm{t}=0$, respectively.

Effect of reduction temperature: The variation of the reduction extent of $\mathrm{MgO}$ in slag at different temperatures is given in Fig. 2. The reduction experiments were carried out under vacuum for $1 \mathrm{~h}$ and $\mathrm{n}(\mathrm{Si}) / \mathrm{n}(2 \mathrm{MgO})$ ratio of 1.0 . The increase of reduction temperature from 1773 to $1873 \mathrm{~K}$ enhanced the reduction extent of $\mathrm{MgO}$ from 73.1 to $91.4 \%$, respectively.

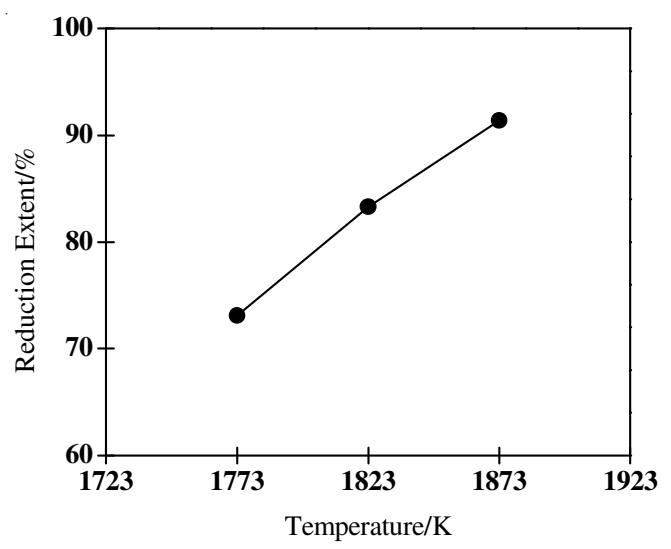

Fig. 2. Effect of temperature on the reduction extent of $\mathrm{MgO}$ in slag

From macroscopical pictures in Fig. 3, it is clearly observed that most of the charges didn't melt at $1773 \mathrm{~K}$ and reduction reaction took place mainly between solid oxide and liquid metal. When reduction temperature was above $1823 \mathrm{~K}$, the charges formed melting slag and reduction became liquidliquid reaction, so reaction rate accelerated with the increase of reduction extent of $\mathrm{MgO}$.

The X-ray diffraction patterns of the primary slag in the absence of reductant and the residue after reaction with ferrosilicon at $1823 \mathrm{~K}$ for $1 \mathrm{~h}$ were shown in Fig. 4. The XRD analysis of the primary slag without reductant at high

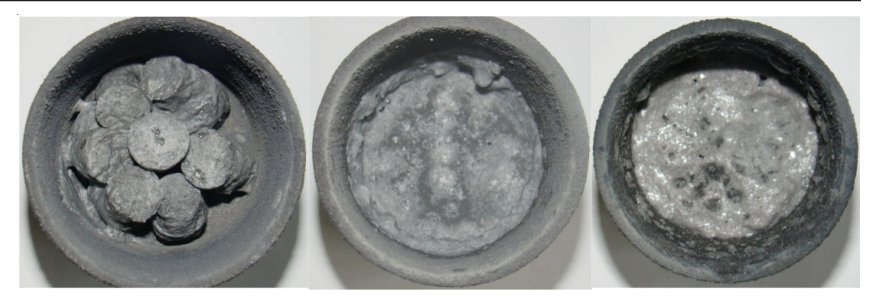

Fig. 3. Macroscopical pictures for residue at different redution tempeture

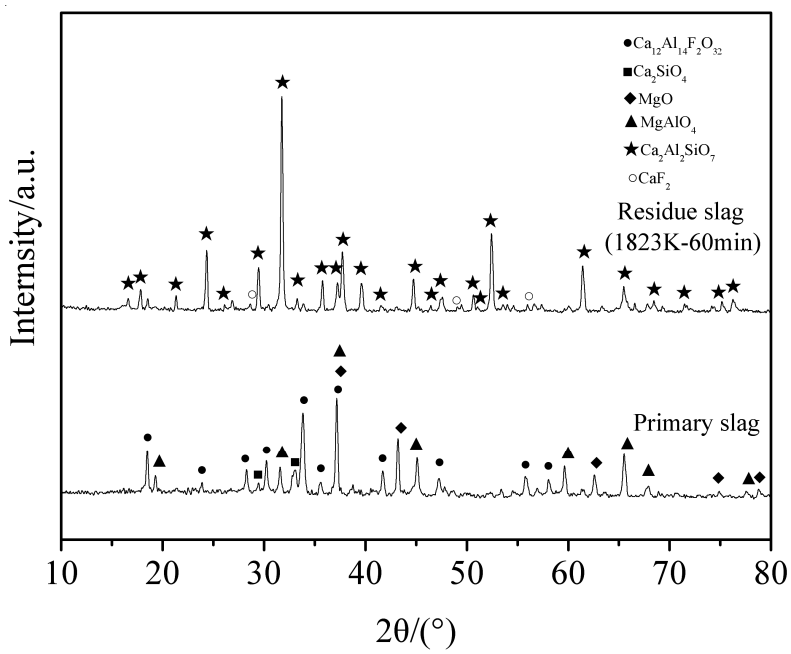

Fig. 4. XRD patterns of the slags in the absence of reductant and after reaction with ferrosilicon at $1823 \mathrm{~K}$ for $1 \mathrm{~h}$

temperature revealed the formation of the phases $\mathrm{Ca}_{12} \mathrm{Al}_{14} \mathrm{~F}_{2} \mathrm{O}_{32}$, $\mathrm{Ca}_{2} \mathrm{SiO}_{4}$ and $\mathrm{MgAlO}_{4}$ as well as $\mathrm{MgO}$. After the reaction of the primary slag and ferrosilicon at a constant temperature of $1823 \mathrm{~K}$ for $1 \mathrm{~h}$, the main phase in residue slag was $\mathrm{Ca}_{2} \mathrm{Al}_{2} \mathrm{SiO}_{7}$. The results indicated that the disappearance of the phases $\mathrm{MgAlO}_{4}$ and $\mathrm{MgO}$ and the formation of $\mathrm{Ca}_{2} \mathrm{Al}_{2} \mathrm{SiO}_{7}$ were due to the reduction of $\mathrm{MgO}$ by $\mathrm{Si}$ in molten slag.

Effect of reduction time: The variation of the reduction extent of $\mathrm{MgO}$ in slag at different time was given in Fig. 5 and reduction experiments were carried out at 1823 and $1873 \mathrm{~K}$ for $\mathrm{n}(\mathrm{Si}) / \mathrm{n}(2 \mathrm{MgO})$ ratio of 1.0 . The reduction extent of $\mathrm{MgO}$ increased from 80.3 to $91.7 \%$ when the reation time prolonged from 30 to $120 \mathrm{~min}$ at $1823 \mathrm{~K}$. The reduction extent of $\mathrm{MgO}$ increased from 81.7 to $97.0 \%$ as the reation time prolonged from 30 to $120 \mathrm{~min}$ at $1873 \mathrm{~K}$, respectively.

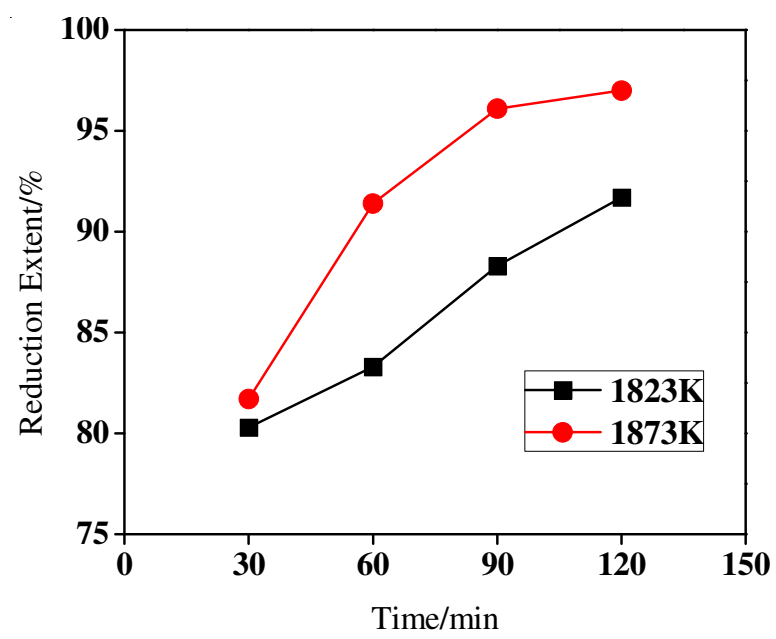

Fig. 5. Effect of time on the reduction extent of $\mathrm{MgO}$ in slag 
The XRD patterns of the residues after smelting reduction process between the experimental slag and ferrosilicon at 1823 $\mathrm{K}$ for $30 \mathrm{~min}$ and $120 \mathrm{~min}$ were shown in Fig. 6. It was noticed that the phases of $\mathrm{MgAlO}_{4}$ and $\mathrm{Ca}_{2} \mathrm{Al}_{2} \mathrm{SiO}_{7}$ were both present with lower intensity in the residue slag for a shorter reduction time of $0.5 \mathrm{~h}$ while $\mathrm{MgAlO}_{4}$ phase disappeared and $\mathrm{Ca}_{2} \mathrm{Al}_{2} \mathrm{SiO}_{7}$ phase was present with higher intensity in the residue slag for a longer reduction time of $2 \mathrm{~h}$. Based on the analysis results of the reduction extent of $\mathrm{MgO}$ in Fig. 5 and XRD patterns in Fig. 6, it is suggested that reduction reaction is not complete and the residue slag contains a small amount of $\mathrm{MgAlO}_{4}$ at $1823 \mathrm{~K}$ for $0.5 \mathrm{~h}$. With prolonging reaction time, the rest of the $\mathrm{MgAlO}_{4}$ in slag was reduced continuously and more $\mathrm{Ca}_{2} \mathrm{Al}_{2} \mathrm{SiO}_{7}$ was generated, so the diffraction peaks of the $\mathrm{MgAlO}_{4}$ disappeared while the peaks of the $\mathrm{Ca}_{2} \mathrm{Al}_{2} \mathrm{SiO}_{7}$ became higher when smelting reduction process was carried out at $1823 \mathrm{~K}$ for $2 \mathrm{~h}$.

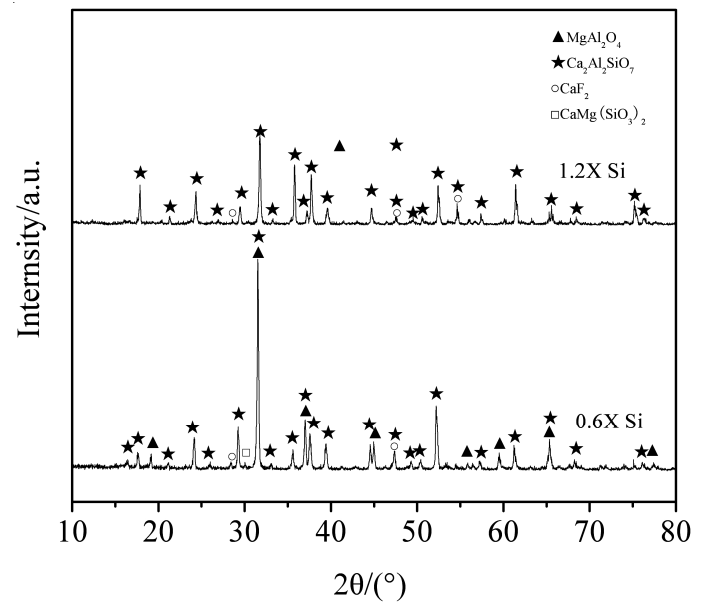

Fig. 6. XRD patterns of the residues after smelting reduction process at $1823 \mathrm{~K}$ for $30 \mathrm{~min}$ and $120 \mathrm{~min}$

Effect of silicon stoichiometry: The variation of the reduction extent of $\mathrm{MgO}$ in slag added as a fuction of silicon stoichiometry to charge was given in Fig. 7. The reduction experiments were carried out at $1823 \mathrm{~K}$ for $30 \mathrm{~min}$ and 120 min. The silicon stoichiometry in the mixture was calculated according to eqn. 1 . At a short reduction time of $0.5 \mathrm{~h}$, the reduction extent of $\mathrm{MgO}$ increased from 49.3 to $83.5 \%$ as silicon stoichiometry increased from 0.6 to $1.2 \mathrm{X}$. When reduction time prolonged $2 \mathrm{~h}$, the reduction extent of $\mathrm{MgO}$ increased from 58.4 to $91.9 \%$ while silicon stoichiometry increased correspondingly from 0.6-1.2 X.

The XRD patterns of the reduction residues for different silicon stoichiometry added to charge at $1823 \mathrm{~K}$ for $2 \mathrm{~h}$ is shown in Fig. 8. It was found that the main phases, identified as $\mathrm{MgAlO}_{4}$ and $\mathrm{Ca}_{2} \mathrm{Al}_{2} \mathrm{SiO}_{7}$ in the residues for the charge containing 0.6XSi and $\mathrm{Ca}_{2} \mathrm{Al}_{2} \mathrm{SiO}_{7}$ in the sample of $1.2 \mathrm{XSi}$ The presence of $\mathrm{MgAlO}_{4}$ in the residues for the charge containing $0.6 \mathrm{XSi}$ was due to lack of sufficient reductant. With the increase in silicon stoichiometry, more and more $\mathrm{MgAlO}_{4}$ in slag was reduced by $\mathrm{Si}$. The absence of $\mathrm{MgAl}_{2} \mathrm{O}_{4}$ phase and stronger characteristic peaks of $\mathrm{Ca}_{2} \mathrm{Al}_{2} \mathrm{SiO}_{7}$ phase in the $1.2 \mathrm{XSi}$ sample are due to sufficient active $\mathrm{Si}$, an excess of which can promote the reduction of residual $\mathrm{MgAlO}_{4}$ and the formation of more $\mathrm{Ca}_{2} \mathrm{Al}_{2} \mathrm{SiO}_{7}$ in the slag.

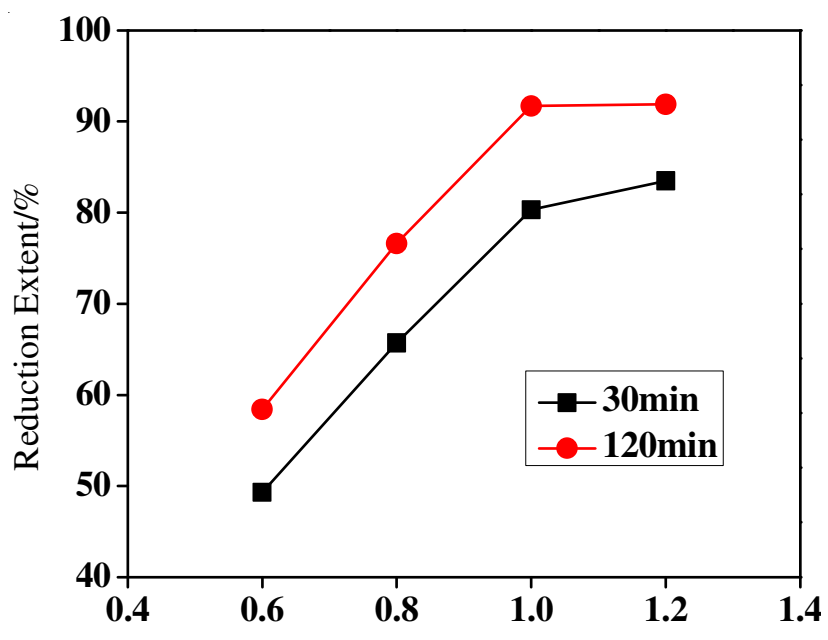

Silicon Stoichometric Amount/X

Fig. 7. Effect of silicon amount on the reduction extent of $\mathrm{MgO}$ in slag

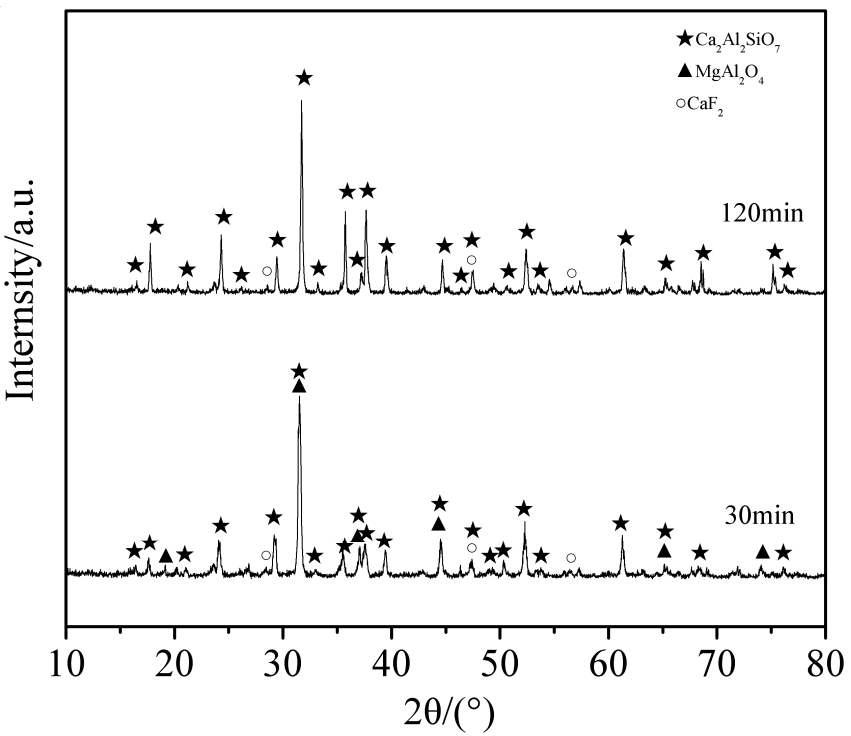

Fig. 8. XRD patterns of the reduction residues for different silicon stoichiometry added to charge at $1823 \mathrm{~K}$ for $2 \mathrm{~h}$

\section{Conclusion}

- The thermodynamics analysis of smelting reduction of $\mathrm{MgO}$ by ferrosilicon indicated that the molten slag of the compositon $55 \%$ calcined dolomite $(32 \% \mathrm{CaO}$ and $23 \%$ $\mathrm{MgO}), 35 \% \mathrm{Al}_{2} \mathrm{O}_{3}$ and $10 \% \mathrm{SiO}_{2}$ could reduced by ferrosilicon at $1873 \mathrm{~K}$ under atmosphere.

- The smelting reduction experiments were carrid out under vacuum for avoiding re-oxidation of $\mathrm{Mg}$ vapour and protecting carbon tube furnace. With the increase in the reduction temperature as well as reduction time and silicon stoichiometry, reduction extent of $\mathrm{MgO}$ improved. Reduction extent of $\mathrm{MgO}$ was achieved up to $97.0 \%$ when using the optional parameters of reaction temperature of $1873 \mathrm{~K}, \mathrm{n}(\mathrm{Si}) /$ $\mathrm{n}(2 \mathrm{MgO})$ ratio of 1.2 and reduction time of $2 \mathrm{~h}$.

\section{ACKNOWLEDGEMENTS}

The work was sponsored by Chongqing Science and Technology Commission under contract No. CSTC2009AB4109. 


\section{REFERENCES}

1. T.Y. Zuo and W.B. Du, J. Guangdong Nonferr. Met., 15, 1 (2005).

2. F. Gao, Z.R. Nie and Z.H. Wang, Trans. Nonferr. Met. Soc. China, 18, 749 (2008)

3. B. Sarma, A.W. Crambler and R.J. Fruehan, Metall. Mater. Trans. B, 27, 717 (1996).

4. G.G. Richards, J.K. Brimacombe and G.W. Toop, Metall. Mater. Trans. $B, 16,513$ (1985).

5. P.R. Taylor and W.M. Wang, Plasma Chem. Plasma Process, 22, 387 (2002).

6. S.Q. Guo, G.C. Jiang and J.L. Xu, J. Iron Steel Inst., 7, 1 (2000).
7. R. Winand, Trans. Inst. Min. Metall. Sect. C, 99, 105 (1990).

8. M. Halmann, A. Frei and A. Steinfeld, Ind. Eng. Chem. Res., 47, 2146 (2008).

9. J.R. Wynnyckyj and L.M. Pidgeon, Metall. Mater. Trans., 4, 979 (1971).

10. R.T. Li, W. Pan, S. Masamichi and J.Q. Li, Thermochim. Acta, 390, 145 (2002).

11. I.M. Morsi, K.A. Elbarawy, M.B. Morsi and S.R. Abdeigawad, Can. Metall. $O$, 41, 15 (2002).

12. J.D.T. Capocchi and V. Rajakumar, Magnesium Technology, Proceedings of the Symposium Sponsored by the Light Metals Division of the Minerals, Metals \& Materials Society, USA, pp. 53-63 (2000).

13. Q.F. Tang, J.C. Gao and X.H. Chen, J. Chongqing Univ., 34, 65 (2011). 